\title{
Social Criticism and the Exclusion of Ethics*
}

\begin{abstract}
As Axel Honneth has recently noted, the critical concerns of social philosophers during the past three decades have been focused primarily on questions of justice, with ethical issues about the human good being largely excluded. In the first section I briefly explore this exclusion in both 'Anglo-American' political philosophy and 'German' critical theory. I then argue, in the main sections, that despite this commitment to their exclusion, distinctively ethical concepts and ideals can be identified both in Rawls's Theory of Justice and in Habermas's Theory of Communicative Action, taking these as exemplary, representative texts for each theoretical school. These ethical elements, and their implications for the critical evaluation of economic institutions, have gone largely unnoticed. In the final section I indicate the kinds of debates that might be generated, were these to be given the attention they arguably deserve. I focus especially on the significance of empirical issues, and hence on the role of social science in social criticism.
\end{abstract}

\section{Social Criticism without Ethics}

Towards the end of his 2005 Tanner Lectures, Axel Honneth nicely characterises the recent past of social criticism in the following terms:

"In the last three decades, social criticism has essentially restricted itself to evaluating the normative order of societies according to whether they fulfil certain principles of justice. Despite its success in justifying some normative standards and despite its efforts at differentiating the various fundamental aspects involved in the act of defining such standards, this approach has lost sight of the fact that violating generally valid principles of justice is not the only way in which a society can show itself to be normatively deficient." (Honneth $2005,134)$

* This is a revised version of a paper given at the International Association for Critical Realism conference at King's College, London in July 2008; it also incorporates revised material from a paper on Habermas presented some years ago to the Social and Political Theory seminar at Sussex University. I am especially grateful to Keith Breen for discussion of many of the issues explored in this paper. 
He goes on to comment:

"This restriction cannot be justified with reference to the fact that democratic societies evaluate their own social and political orders primarily in relation to standards of justice, because deliberations within the democratic public sphere are constantly confronted with issues and challenges that raise the question of whether particular social developments might be regarded as desirable beyond all considerations of what is just." (2005, 135)

These issues 'beyond considerations of justice' are, as Honneth also notes, often termed ethical, in the sense that they involve questions about the good, or the good life for humans, as distinct from questions about the right, including issues of justice. It is social criticism with a distinctively ethical character that has largely been absent during this period, an absence that he clearly regrets, as I do. ${ }^{1}$ Thus in the specific case of economic institutions - which Honneth does not mention here, but will be the main focus of this paper - what has largely been excluded is their critical evaluation in terms of the kinds of lives they facilitate or hinder, as distinct from the justice or injustice of the unequal chances that different social groups may have to achieve these.

This restriction of social criticism to questions of justice or right (to which questions of democracy might also be added) is not arbitrary or fortuitous. It has been provided with elaborate rationales within two major theoretical sources of social criticism during this period: the broadly analytical school of 'AngloAmerican' political philosophy, in relation to which Rawls's Theory of Justice is an exemplary, if not founding, text, and the 'German' school of critical social theory, in relation to which Habermas's Theory of Communicative Action has a comparable status. ${ }^{2}$ In both, it can be argued, substantive ethical judgments about the good are, as a matter of philosophical principle, excluded as a basis for, respectively, political action and social criticism.

However, in the main sections of this paper I shall argue that despite this commitment to their exclusion, distinctively ethical concepts and ideals can in fact be identified in both of these texts, and that if one follows through their theoretical implications, what we are presented with in each case is a possible basis for the critical evaluation of economic institutions on substantive ethical grounds. But before trying to show that this is so, I shall say more about the respective commitments of 'political philosophy' (for short) and 'critical social theory' to the exclusion of ethics.

In the former, it is the principle of neutrality that has been especially influential, despite its many critics. According to this principle, "[...] government

\footnotetext{
1 But Honneth conceptualises these 'excluded' ethical questions in terms of social pathologies and explores them through ontological claims, an approach that differs from the one I shall take here, so I do not wish to suggest that he would support what I argue in this paper.

2 See Honneth 1996, where he contrasts the different conceptions of social philosophy associated with these. Honneth would no doubt question my attribution to Habermas of an 'ethics exclusion principle', but this is partly because he includes within 'ethics' (what I shall later call) both 'substantive' and 'procedural' evaluations, whereas my focus is only on the exclusion of substantive ethical judgments: see section 3 below.
} 
must be neutral on what might be called questions of the good life", and "[...] political decisions must be, so far as is possible, independent of any particular conception of the good life, or of what gives value to life". Individuals differ in their conceptions of the good, and "[...] the government does not treat them as equals if it prefers one conception to another [...]".

This characterisation of neutrality was provided by Ronald Dworkin, in his much cited paper on the nature of liberalism published in 1978 (Dworkin 1978[1985], 191). Liberalism, he argued, is best understood in terms of its commitment to this principle of neutrality. It is this that distinguishes it from nonliberal theories, according to which:

"[...] the treatment government owes citizens is at least partly [to be] determined by some conception of the good life. Many political theorists share that thesis, including theories as far apart as, for example, American conservatism and various forms of socialism or Marxism, though these differ in the conception of the good life they adopt, and hence in the political institutions and decisions they endorse. In this respect liberalism is decidedly not some compromise or halfway house between more forceful positions, but stands on one side of an important line that distinguishes it from all competitors taken as a group." (1978[1985], 192)

Thus from the standpoint of liberalism, defined in this way, all nonliberal positions are, as it were, equally mistaken: despite the major disagreements between them about what the good life for humans consists in, what is most important about them is the one thing they have in common, their view that governments should base their actions on some such conception of the good, rather than on none. For the liberal, according to Dworkin (i.e. for 'neutralist liberalism'), these disagreements simply do not matter: what had been central issues for socialists, conservatives and others - including liberals, 'prior' to this neutralist understanding of liberalism - and a major source of their opposition to one another, need no longer be of any concern. Debates about the good life for humans can safely be ignored by political philosophers, at least to the extent that they are interested, as they should be, in determining the aims which governments should pursue.

So the principle of neutrality, which restricts the grounds for state action by excluding ethical considerations as illegitimate, also restricts the scope of discourse in political philosophy, by excluding ethical debate as irrelevant. Nor is this the full extent of the latter exclusion. The 'traditional' concerns of socialist, conservative and liberal theorists with ethical issues went hand in hand with an interest in broadly empirical questions about the conditions in which their favoured conceptions of the good could, or could not, to be realised, and hence also in the claims of the classical social theorists (and classical political economists), much of whose work was guided, at least in part, by specific ethical standpoints. For the neutralist political philosopher, this 'classical tradition' can likewise can be regarded as irrelevant (though not, of course, when it has a bearing on issues of justice). 
An obvious example is Marx's 'humanist' critique of capitalism in his early writings. Capitalist market economies are condemned for their alienating character: they prevent people developing and exercising the human capacity for self-expressive work, and encourage social relationships based (at best) on mutual indifference. This critique may itself be criticised on two (logically distinct) grounds: empirically, for example by arguing that alienated labour is due to a certain kind of industrial production and not to the capitalist form of ownership; and normatively, for example by arguing that production is not the most valuable kind of human activity (by comparison, say, with social activities and relationships associated with reproduction).

But for Dworkin's neutralist liberal, the kinds of issues raised by either of these responses are of no concern for political philosophy, nor by implication for social criticism aimed at shaping government action. One should not try to evaluate economic institutions in terms of their success or failure in enabling the realisation of particular conceptions of the good, since the outcome of such an evaluation would not be a legitimate basis for state action aimed at establishing or removing those institutions. Instead, they should be evaluated on a quite different basis, namely the extent to which they succeed in not 'favouring' any one conception of the good over others, i.e. for their consistency with the principle of neutrality. And Dworkin argues that market economies broadly succeed in meeting this requirement. ${ }^{3}$

Despite its major influence on political philosophy, neutralist liberalism has by no means been an uncontested orthodoxy during this thirty year period. Yet in terms of the extent to which mainstream political philosophers have engaged in the substantive ethical evaluation of economic institutions, it is almost as if that had been so. Both communitarian critics of liberalism, and perfectionist liberal critics of neutralist liberalism, have argued for the importance of ethics in political philosophy and its legitimacy as a basis for government action. But whereas neutralist liberals have engaged in a highly productive series of theoretical and practical debates about substantive questions of economic and social justice (and of 'right' more generally), nothing remotely equivalent to this has been generated by critics of liberal neutrality. For various reasons, which I will not explore here, there has been little substantive engagement with earlier traditions of ethical debate about economic institutions.

The most notable exception to this is provided by the determinedly (and in my view unnecessarily: Keat 2008a) anti-liberal work of Alasdair MacIntyre. In After Virtue (MacIntyre 1981) and later work (1994; 1998; 1999), MacIntyre re-shapes both Marx's ethical critique of capitalism and Weber's critical understanding of rationalisation through the development of his quasi-Aristotelian concept of social practices, with their internal goods and standards of excellence, and argues both that modern market economies are inimical to the conduct of

\footnotetext{
3 Thus Dworkin argues that one should not, as a liberal, criticise economic growth (and by implication, economic systems that generate this) on the grounds that it is inimical to a conception of the good that values 'the simple life' and 'living in harmony with nature', as against high levels of consumption etc.. Regulation of the market required by this ideal to prevent damage to the natural environment would only be justifiable if one could show that the ideal was being unfairly discriminated against (Dworkin 1978[1985], 202).
} 
economic production as a practice, and that practices more generally occupy only a marginal position in modern society. ${ }^{4}$

MacIntyre's work thus differs from the mainstream not only in its substantive ethical evaluation of modern economic institutions, but also in its engagement with classical social theory. In this latter respect, at least, it has something in common with that of Habermas, the key figure in the second major theoretical source of social criticism during this period noted earlier. In particular, Habermas's account of colonisation, the central critical concept in The Theory of Communicative Action (henceforth TCA) is developed and presented through an elaborate engagement with his classical predecessors. But unlike MacIntyre, substantive ethical evaluation of modern economic institutions is studiously avoided; correspondingly, the classical tradition of social theory is 'pruned' of distinctively ethical elements. ${ }^{5}$

In particular, Marx's ethical critique of capitalism is put aside, not because of its empirical errors, or the substantive inadequacy of its conception of the good life, but because theories of the good are seen as inappropriate grounds for social critique. This is partly because, during the (long) period of his work to which $T C A$ belongs, Habermas clearly regarded ethical judgments as cognitively deficient, in that their claims cannot be evaluated through any recognisable form of rational argumentation. In this respect they were seen as markedly inferior to moral ones.

This view changed to some extent in his later work on legal and political theory, Between Facts and Norms, where he provides an account of ethical reasoning and argues for its inclusion (alongside moral reasoning about matters of justice) in political deliberation (Habermas 1996; also 1993). ${ }^{6}$ In doing so, he can thus be seen as rejecting the neutralist liberal exclusion of ethics from politics. He conceives of ethical-political reasoning as a process of critical reflection on their shared identity and traditions by the members of a political community, and this account has a good deal in common with the way in which communitarian political philosophers have understood the nature political argument.

\footnotetext{
${ }^{4}$ It might be argued that another notable exception is Nussbaum's Aristotelian account of human functionings and capabilities (Nussbaum 1990; 2000). I shall point later (section 5) to the importance of this for the justification of MacIntyre's endorsement of practices, but in the present context it should be noted that although insisting on the centrality of 'goods', her focus has been mainly on their role in issues of justice.

${ }^{5}$ These are not, of course, the only schools of social criticism that have been influential during this period. In particular, the various forms of postmodern thought have also excluded ethically-based social criticism. But unlike the two that I consider here, they do not distinguish between ethical and non-ethical normative judgments. Both are viewed with equal scepticism, epistemologically, and criticised as arbitrary social constructions concealing relations of power. Evaluating the desirability of some such constructions by comparison with others, whether on ethical or moral grounds, is typically eschewed.

${ }^{6}$ See Cooke 1997 on this shift of view, and Warnke 1995 more generally on Habermas's conception of ethics. Interpretation of Habermas's work is always problematic, and within the scope of this paper I cannot justify most of the assertions I make about this (I try to do so in Keat 2007). But for the crucial argument about colonisation presented in section 4, I try to provide appropriate textual support.
} 
But unlike the communitarians, Habermas not only restricts this model of critical self-understanding to ethical reasoning, providing a quite different model for issues of justice, but he also insists on distinguishing between what can legitimately be done by the members of a political community and what can legitimately be done by (critical) theorists. In particular, he continues to endorse the exclusion of ethics from critical social theory, and hence from 'social criticism' conceived as the application of this to specific features of the social world: the position adopted in $T C A$ is in this respect retained.

However, I shall argue in sections 4 and 5 -and this will be the central claim about Habermas in this paper - that in fact, Habermas by no means succeeds in excluding ethics from $T C A$, his most important work of critical social theory. Through a detailed examination of what is said in, and implied by, certain crucial passages in this text, I shall try to show that colonisation, the central critical concept of $T C A$, is conceived and criticised in ways that include elements of a distinctively ethical character. But before doing so, in sections 2 and 3 I shall also argue that something similar is true of Rawls's Theory of Justice. For despite this text being generally regarded as a locus classicus of neutralist liberalism, one can find 'buried' within it, in a largely neglected section, a basis for just that kind of ethical evaluation of economic institutions and practices which has been excluded by the dominant forms of social and political philosophy in recent decades.

\section{Rawls: Private Society and Social Unions}

In section 79 of A Theory of Justice (Rawls 1971[1999]: henceforth TJ), "The Idea of Social Union", Rawls addresses the question of whether - as many of his communitarian critics were later to argue - "the contract doctrine entails that private society is the ideal" (458). He argues first that this is not so, and then goes on to reject the ideal of private society, endorsing instead that of social unions.

Private society, he says, is a "form of social order" in which individuals (and associations) pursue their own ends that are independent of, and may sometimes compete with, those of others, and value institutions only instrumentally in relation to these. It is true, he says, that individuals in the original position are characterised in just this way, but to think that this implies private society as the ideal is to misunderstand the theoretical rationale for doing so. The point is not that this is the only or best way in which people can act and relate to one another, but rather that principles of justice are designed to address the conflicts of interest and competing demands that arise if and when they do so. What is assumed or implied by the contract doctrine is not that private society is the ideal, but that the 'circumstances of justice' obtain.

That private society is not the ideal can be shown, says Rawls, by attending to "[t]he account of goodness as rationality and the social nature of mankind" (458). But this sociability "must not be understood in a trivial fashion" (458), as it would be if it were thought to consist only in facts such as the following: 
that society is necessary for human life, including the ability to speak and think; that by living together, people acquire needs and interests that prompt them to cooperate for mutual advantage through their institutions, and that the concepts they use to describe their wants and purposes often presuppose social settings and beliefs rooted in longstanding traditions (458). These facts, he says, are not themselves trivial, but they provide us with a trivial interpretation of human sociability, because "all of these things are equally true of persons who view their relations purely instrumentally" (458). I take it that he means by this that they are true of private society, and hence cannot serve to distinguish this from some preferable ideal.

To do this one has to identify a form of sociability that is distinct from (what I shall call) the 'generic' sociality that even private society displays. This, he says, can be found in social unions. Human societies contain a multitude of these, and of many different kinds, including families and friendships, sports and games, and the arts and sciences (460). In social unions, individuals pursue inherently complementary ends, and value institutions and the social activities that take place within them for their own sake, rather than instrumentally. Along with the specific motivations of participants and the aims of the activity concerned, there is the shared end of the activity itself being conducted well, so that for everyone involved, "the successes and enjoyments of others are necessary for and complementary to [their] own good" (458).

Further, he argues, when people acquire a sense of confidence and competence through their engagement in some particular social union, they will view the existence of other such unions as providing them with an extended sense and enjoyment of human possibilities, and indeed ultimately of the common achievements and capacities of humankind. They can thus overcome the limitations imposed by the fact that, for any individual, there are abilities they have that they will not be able to develop and exercise, if they are to become sufficiently proficient to enjoy these properly, and there are many others that only other individuals possess.

In this respect, Rawls says, the ideal of social unions - which he says can be found in the work of von Humboldt - differs from Marx's ideal, since Marx viewed "full communist society as one in which each person completely realizes his nature, in which he himself expresses all of his powers" (460, note 4$){ }^{7}$ Against this, Rawls insists that a "well-ordered society does not do away with the division of labour in the most general sense". Rather, he declares: "The division of labour is overcome not by each becoming complete in himself, but by willing and meaningful work within a just social union of social unions in which all can freely participate as they so incline." $(464)^{8}$

\footnotetext{
7 Rawls notes that some commentators have attributed the 'social union' position to Marx, but he thinks this is not so; no doubt he has in mind the passage in The German Ideology about hunting, fishing and philosophising. He also comments that Marx's ideal does not sufficiently recognise our mutual dependence.

8 In later work Rawls rejected the idea of society as itself a social union, but this does not affect the issues I shall address here. The broader aim of section 79 is to show the 'congruence' of the good and the just. My discussion abstracts from this broader project and hence ignores
} 
Having outlined Rawls's view of private society and social unions, and his critical though by no means unsympathetic response to Marx, I want now to consider what the ideal of social union implies for the nature of economic institutions: what kind of economic system is required, if this ethical ideal is to be realised? In particular, could a market economy be acceptable from this standpoint? On the face of it, surely not, since Rawls apparently regards market economies as paradigmatic cases of private society. Thus early on in section 79 , in introducing this concept, he says that "[t]he theory of competitive markets is a paradigm description of this type of society" (457), and that "[t]he natural habitat of this notion is in economic theory (general equilibrium)" (457, note 3$).^{9}$

Indeed, it would seem that Rawls has provided the basis for a radical criticism of market economies on distinctively ethical grounds. An obvious parallel here would be with MacIntyre's critique of the market in After Virtue, on the grounds that market economies are antithetical to the conduct of economic production as a practice, and that in market societies, practices are of marginal significance in social life. For Rawls's conception of social unions has a great deal in common with MacIntyre's conception of practices. ${ }^{10}$

But no such ethical critique of market economies is in fact presented by Rawls, either in this section of $T J$ or elsewhere. Indeed, he never mentions the possibility of rejecting them on these grounds. And were he to do so, this would be problematic for him, since in earlier sections of $T J$ (41-43), he argues that his principles of justice can only be realised in a market economy. The requirements of justice would thus clash with those of goodness. So I will now consider how Rawls might avoid this problem, i.e. how he might justify a more favourable view of market economies than the critical argument just sketched would imply. I shall do so mainly by exploring his views about the possibility of meaningful work in market economies. ${ }^{11}$

Rawls's discussion of how a just society, as a social union of social unions, has the good of justice as its shared end.

${ }^{9} \mathrm{He}$ also notes that the concept of private society can be found in Hegel's account of civil society in The Philosophy of Right, drawing on Adam Smith. But Rawls is surely wrong to regard this concept as 'at home' in neo-classical economics, which fails to recognise what I have called the 'generic sociality' of private society, and hence of market economies. By contrast, Durkheim's 1893(1984) 'social' understanding of contract in private society is exemplary.

${ }^{10}$ This is reflected in their use of more or less the same set of examples of the two. See also MacIntyre's distinction between individualistic and non-individualistic conceptions of 'common goods', which mirrors Rawls's distinction between private society and social unions (MacIntyre 1998).

11 The significance Rawls attaches to work is indicated elsewhere in $T J$ : "It is a mistake to believe that a just and good society must wait upon a high material standard of life. What men want is meaningful work in free association with others, these associations regulating their relations to one another within a framework of just basic institutions. To achieve this state of things great wealth is not necessary. In fact, beyond some point it is more likely to be a positive hindrance, a meaningless distraction at best, if not a temptation to indulgence and emptiness." (TJ, 257-258) 


\section{Rawls: Social Unions and Market Economies}

The first move Rawls would need to make is to distinguish between two sets or kinds of activities and relationships in market economies: (i) those involved in exchange and competition, between both individuals and firms, and (ii) those that take place within firms. This distinction is important because the case for saying that market economies display the features of private society (rather than social union) applies most obviously to (i), and not to (ii); and from the fact that it is true of (i), it does not follow that it is true also of (ii). (After all, the best way for firms to succeed in a market economy just might be to encourage the conduct of production as a social union amongst its workers).

By distinguishing between 'market' relations of exchange and competition, and the activities and relationships within firms, it becomes at least intelligible that the latter might display features of social union, despite the former not doing so. And it seems that Rawls thinks this (or something like it) is not just a conceptual possibility but a real one, since he claims that what he calls meaningful work (for everyone) is an achievable goal in a "well-ordered society" (463-464), and since he believes that such a society must utilise the market, that this is possible in market economies. In such a society, he says, "the worst aspects" of the division of labour can be surmounted:

" [... ] no one need be servilely dependent on others and made to choose between monotonous and routine occupations which are deadening to human thought and sensibility. Each can be offered a variety of tasks so that the different elements of his nature find a suitable expression." (463-464)

Rawls is well aware that many or most actual market economies fail to provide such work for many or most of their members. The same is true in the case of justice: although market economies are necessary for his principles of justice to be realised, he recognises that in actual market economies this generally fails to happen. But this, he argues, is at least partly because it is only certain kinds or forms of market economy that are compatible with the realisation of these principles ( $T J$ sections 41-43). The argument (and typology) is more fully developed in his later book, Justice as Fairness (Rawls 2001), where he distinguishes:

"[...] five kinds of regimes viewed as social systems, complete with their political, economic and social institutions: (a) laissez-faire capitalism; (b) welfare-state capitalism; (c) state socialism with a command economy; (d) property-owning democracy; and finally (e) liberal (democratic) socialism [i.e. what is usually termed 'market' socialism]." (Rawls 2001, 136)

Rawls argues that only (d) and (e) are compatible with the effective operation of his principles of justice; he is especially concerned to show the superiority of (d) to (b) in this respect. (In the Preface to the revised, 1999 edition of TJ, he says he wishes he had given more attention to this in the first edition). Crucially, 
whereas in welfare state capitalism people are in effect compensated for low earnings, lack of employment etc. by financial transfers, in a property-owning democracy (Meade 1964) there is an attempt to significantly reduce inequalities in people's productive assets, especially their knowledge, skills and other forms of 'human capital'.

It might then be argued that this puts workers in a better position to bargain with employers, and equips them for reasonably interesting kinds of work. In doing so - though Rawls does not make this connection explicitly - it might also solve or significantly mitigate the problems of 'servility' and 'monotony', the absence of which, as we have seen, is central to his view of meaningful work. Admittedly, this would not be enough to show that 'work as a social union' would be achieved in this kind of regime, since the absence of servility and monotony does not necessarily bring with it the existence of 'shared final ends' and the valuing of activities and institutions 'for their own sake'. But Rawls could suggest that the second of his two 'justice-compatible' regimes, liberal (or market) socialism, might do better than property-owning democracies in this respect. ${ }^{12}$

Of course, even if there were some kind of market economy that is compatible with work as a social union, the presence of relationships of competition and exchange (which are features of any market economy) would mean that private society remained as a significant element in such a regime. But whether this implies that no form of market economy is consistent with Rawls's ethical position depends on precisely how one interprets his 'rejection' of 'the ideal of private society'. If this is taken to mean that there is no place for this 'form of social order', and that every domain of society should instead possess the character of social unions, then market economies must be regarded (by Rawls) as inherently undesirable, in ethical terms. But an alternative, and more plausible interpretation might be that Rawls is only rejecting private society as the ideal in the sense that he is opposed to societies that are exclusively, or predominantly, private in character, and favours those that possess an extensive array of social unions in many, though not necessarily all, domains. ${ }^{13}$

So provided that the market's private character does not prevent the flourishing of social unions in other, non-economic domains, there would be no need for Rawls to reject market economies 'in the name of social unions'. This proviso is crucial, though Rawls does not draw attention to it, perhaps because he thinks it is obviously met by the multitude of social unions of various kinds that he regards as typical of modern liberal societies. ${ }^{14}$ But other social philosophers (amongst them, Habermas) view the meeting of this proviso as potentially problematic,

\footnotetext{
12 Further, although Rawls regards meaningful work as very important, he does not accept the privileged ethical status attributed to it by Marx: other kinds of social union are also of considerable value. So he might argue that even if work in market economies falls short of the ideal features of a social union, this could be compensated in other areas of social life.

13 Notice also that relationships between social unions may well involve competition for resources, cooperation 'only' for instrumental purposes, and so on.

14 As Kymlicka notes $(2002,251)$ liberal theorists tend to think that all a flourishing civil society needs is the absence of state intervention and the presence of entry and exit rights for the members of associations.
} 
arguing that in market economies, the economy has an inherent tendency to colonise other, non-economic domains: that is, to replicate its character across the whole of society. If this were so, the flourishing of social unions in non-economic domains would, at the very least, require specific measures to protect them from colonisation by the market.

In the next two sections I shall go on to examine Habermas's influential analysis of colonisation in The Theory of Communicative Action. But before doing so I will draw out the implications of this discussion of Rawls for the issues about ethics and its place in social criticism that are the central focus of this paper.

One can begin by contrasting what I have described as Rawls's 'critical yet sympathetic' response to Marx with the response that I argued in section 1 is implied by (Dworkin's) neutralist liberalism. Unlike the neutralist liberal, Rawls seems not regard to it as irrelevant, for the purposes of social or political philosophy, to engage in a substantive debate with Marx about his ethical vision of communist society, and the associated criticism of alienated work in capitalist market economies. ${ }^{15}$ Instead, he criticises (what he takes to be) Marx's commitment to ending the social division of labour and provides, in his account of social union, what he regards as a preferable alternative to this. Nor does Rawls defend market economies on the grounds that they alone are consistent with the principle of neutrality. Rather, he thinks it important to compare the different institutional forms that market economies can take, with respect (inter alia) to the availability of meaningful work.

So what Rawls says in section 79 of $T J$ (or at least, what I have argued is implied by what he says) seems clearly at odds with neutralist liberalism. Yet as I noted earlier, $T J$ is normally regarded as a locus classicus of this position, and in section 50 he discusses and rejects what he calls perfectionism, a term usually regarded as interchangeable with 'non-neutrality'. In section 79 he says that his account of social union is determinedly non-perfectionist, since it rejects any attempt to rank the different kinds of social union in terms of some hierarchy of value (462). Indeed, as he notes explicitly, this is why he uses the case of ordinary games, rather than the arts and sciences (which he assumes would be ranked more highly by perfectionists) to illustrate his conception of social unions; likewise, when he talks of 'culture', he includes "high and low" (TJ, 461). And elsewhere in $T J$ he rejects, for example, special measures to support the arts.

But there is surely an important respect in which 'perfectionist ranking' is implied by Rawls's discussion of social unions in section 79, namely the 'ranking' of social unions, of all particular kinds, above private society. That is, although there is no differential evaluation of each kind of social union, the specific form of sociality they have in common - the presence of shared ends, etc. - is being ranked more highly than the specific form of sociality possessed by private society. ${ }^{16}$

\footnotetext{
15 That Rawls took Marx's critique of liberalism seriously is indicated by his responses to this in section 52 of Justice as Fairness (Rawls 2001), a book based on his lecture course at Harvard delivered through the 1980s.

16 It might be objected, against my argument here, that Rawls is opposed to perfectionism only as a principle of distributive justice and, by implication, that in his sense of this term,
} 
And if it is true that government action may be required to ensure that social unions flourish, while private society is kept in its place, it is hard to see why this use of resources (and state powers) should be regarded as legitimate (or consistent with anti-perfectionism), whilst the kind of use that Rawls has in mind (i.e. to support one kind of social union rather than another) is not. That Rawls does not 'notice' the perfectionist implications of what he says about private society and social unions is, I suggest, because he does not consider the possibility that market economies might pose a threat to social unions that would require (what he would regard as problematic) intervention by governments. ${ }^{17}$

\section{Habermas: Colonization without Ethics}

I turn now to Habermas's account of colonization, the central critical concept in his Theory of Communicative Action (henceforth TCA). In the present section I shall outline what might be called his 'official' understanding of this, couched in terms that are consistent with his exclusion of ethics as grounds for social criticism. In the section that follows I shall argue that what he actually says about colonization is at certain points significantly at odds with his official position.

I begin by noting certain 'generic' aspects of the concept of colonization, i.e. ones that can be found not only in Habermas's specific theoretical understanding of this, but also in the work of other social philosophers who, without necessarily using this term, clearly have something like this in mind. ${ }^{18}$ The concept of colonization, I suggest, is especially at home in a widely shared understanding of modern societies as differentiated into various distinct (though not independent) spheres or domains, each with its own characteristic social relationships and institutional forms. Colonisation then consists in features of one such domain being carried over or extended to another, so that the previously distinctive character of this colonised domain is assimilated to that of the colonising one.

Typically, to represent something as a case of colonisation is not only to claim that some such extension or 'displacement' has in fact occurred, but also to make or imply a critical judgment about this. Amongst the various possible grounds for such negative judgments are ethical ones, such as the claim that some valuable kind of good that depended on the specific character of the colonised domain has been lost or damaged through this process. But not every case in which one domain has a supposedly negative impact on another counts as colonization, since this concept is applicable only where the damage consists in, or results from, extension or replication. For example, one might criticize the impact of economic life on how much time people have to spend with their children, but this is not a matter of colonization. By contrast, if people's relationships with

'perfectionism' and (what is usually understood by) 'non-neutrality' are not equivalent. But I shall not explore the issues raised by this possibility.

17 A similarly problematic use of state powers and resources would arguably be involved in government support for one 'regime' rather than another, so as to make meaningful work available to all. See Arneson 1987 for a powerful 'neutralist' argument for leaving it to the market to determine this, and Keat 2009 for a response.

18 Here I draw especially on Walzer 1983; Anderson 1990 and Keat 1993; 2000. 
their children are conducted as if they were relations of economic exchange, it might well be.

This latter case also points to a (rough) distinction that can be made between colonisation that involves the extension from one domain to another of (a) the former's institutional arrangements or mechanisms, and (b) the character or meaning of its social relationships. Thus in the example just noted, it is (b) that is involved: there is no use of the price mechanism, (literal) buying and selling do not take place, and so on. By contrast, the provision of 'parenting services' through a commercial agency would count as a case of (a). Finally, one can also distinguish, amongst social philosophers who use the concept of colonization, between those who think that it is only when the colonizing extension takes place that something undesirable occurs, and those who think that colonization 'spreads even further something that is anyway bad, even within the colonizing domain'. One might locate Marx in the latter group, whilst Habermas clearly belongs to the former, and I shall use the concept of colonization on this understanding from now on.

With these generic features of colonization in mind, we can now consider Habermas's specific theoretical account of this, in the second volume of TCA. This is built on what he regards as a fundamental difference between two forms of rationality, instrumental (or strategic) and communicative. The former is involved in rational-purposive action aimed at the successful achievement of given ends through the calculation and deployment of effective means; the latter in communicative action aimed at reaching understanding or agreement through uncoerced dialogue between the parties concerned. Both kinds of rationality are valuable, but whereas instrumental reason is the appropriate form for what he calls 'the material reproduction of society', its 'symbolic reproduction' relies on communicative reason.

Symbolic reproduction takes place within the lifeworld, comprised of the private (household) sphere and the political and cultural public spheres, which are concerned respectively with 'socialisation', 'social integration' and 'cultural reproduction'. Material reproduction takes place within the system, comprising the economy and the (administrative) state. These differ from the lifeworld spheres not only in utilising instrumental, rather than communicative rationality, but also in the distinctive way in which they coordinate actions, namely through the use of non-linguistic steering media: in the economy, (mainly) money, especially prices as signaling devices; in the state, (mainly) power. ${ }^{19}$ Thus:

"In capitalist societies the market is the most important example of a norm-free regulation of cooperative contexts. The market is one of those systemic mechanisms that stabilize nonintended interconnections of action by way of functionally intermeshing action consequences, whereas the mechanism of mutual understanding harmonizes the action orientations of participants [...] In one case the

19 See TCA II, 318-319 for a useful summary. In discussing colonization I will (unlike Habermas) give more attention to the economy than the state. I exclude altogether Habermas's 'additional' critical concept of 'cultural impoverishment'. 
action system is integrated through consensus, whether normatively guaranteed or communicatively achieved [i.e. pre-modern v. modern]; in the other case it is integrated through the nonnormative steering of decisions not subjectively coordinated." ( TCA II 150; parentheses added $)^{20}$

We are now in a position to present Habermas's specific theoretical conception of colonization. In line with the generic account provided earlier, according to which features of the colonizing domain are carried over into the colonized domain, Habermas conceives of the colonization of the lifeworld as consisting in the instrumental rationality and non-linguistic steering media of the economy and/or state displacing the communicative rationality and consensus-based action coordination of the various lifeworld spheres (although he recognizes that the process could in principle go in the other direction).

But colonization is not only a descriptive but an evaluative, critical concept. On what grounds does Habermas regard this process as undesirable? He argues that the differences between material and symbolic reproduction are such that whereas the former can perfectly well (or even best) be performed on the basis of instrumental reason and media-steered coordination, the latter cannot, so that any attempt to do so will have what he calls 'pathological' consequences. Thus he insists that:

"[... only domains of action that fulfill economic and political functions can be converted over to steering media. The latter fail to work in domains of cultural reproduction, social integration and socialization; they cannot replace the action-coordinating mechanism of mutual understanding in these functions. Unlike the material reproduction of the lifeworld, its symbolic reproduction cannot be transposed onto foundations of system integration without pathological side-effects." ( TCA II 322-323; see also 261, 374-375) ${ }^{21}$

The concept of pathology fits naturally with the (broadly) functionalist terms in which Habermas talks of system and lifeworld. Colonization is damaging because it prevents the crucial functions of lifeworld spheres being performed, so that "[d]isturbances in reproduction are manifested in their proper domains of culture,

\footnotetext{
${ }^{20}$ I will not explore the assumptions underlying the system-lifeworld distinction, but I take it that for Habermas, what belongs to the lifeworld is such that it can, and can only, be understood by an interpretive social science concerned with 'meaningful action', while what belongs to the system is such that it cannot: only a non-interpretive systems theory is appropriate.

21 Habermas wishes not only to criticize colonization, but to resist any corresponding criticism of the historical process through which these economic and political functions, which had been performed within the lifeworld in pre-modern societies, became separated off (or 'decoupled') into the 'systems' of modern societies. Thus: "It is not the uncoupling of media-steered subsystems and of their organizational forms from the lifeworld that leads to the one-sided rationalization or reification of everyday communicative practice, but only the penetration of forms of economic and administrative rationality into areas of action that resist being converted over to the media of money and power because they are specialized in cultural transmission, social integration, and child-rearing, and remain dependent on mutual understanding as a mechanism for coordinating action." (TCA II 330)
} 
society and personality as loss of meaning, anomie, and mental illness (psychopathology)" (TCA II 142). But there are also hints of a somewhat different way of conceptualizing this 'damage': not so much as failure in the performance of essential social functions, but as failure to realize a specific ideal that Habermas endorses and associates with the Enlightenment (TCA II 325-329).

This ideal, and the threat presented to it by colonization, is most easily illustrated in the case of the public political sphere, and especially in Habermas's discussion of this in his later work, Between Facts and Norms (Habermas 1996, ch. 8.3; henceforth $B F N$ ). Amongst the requirements for a flourishing democracy, he argues, is informed public debate, to which broadcasting and journalism can and should make a major contribution. But when they operate on a purely commercial, market-driven basis, they often fail to do so. For example, the mixing of information with entertainment and 'human interest' stories are said by Habermas to contribute instead to a depoliticization of the public sphere ( $B F N$ $373,377)$.

But this is not the only requirement for democracy, he claims. If politics is to be "the practice of self-determination by free and equal citizens" ( $B F N$ 387 ), these citizens must, as individuals, have acquired the capacity for selfdetermination. So Habermas argues that one of the responsibilities of citizens is to ensure that this requirement is met: "[...] enfranchised citizens must, in exercising their public autonomy, draw the boundaries of private autonomy in such a way that it sufficiently qualifies private persons for their role of citizen." $(B F N 417)^{22}$ In discharging this responsibility, citizens will thus be concerned to protect the private sphere of the lifeworld from colonisation. Thus what were presented in TCA as threats to the 'socialisation' function can now be conceived as threats to the development of individual autonomy and hence to the capacities required for democratic citizenship.

So in $B F N$, Habermas criticises colonisation on the grounds that this undermines the social conditions that are necessary to realise the ideal of collective self-determination, including those affecting the development of 'suitable individuals'. Just how far this marks a departure from the quasi-functionalist approach in TCA need not concern us here. Nor does it matter whether Habermas would himself conceptualise these kinds of concern about colonisation as ethical in nature. Rather, what is crucial for my purposes is that Habermas would clearly be opposed to the critical social theorist going beyond the limits of this kind of criticism. That is, what he rules out are critical judgments about the specific content or character of the lives that people lead, the kinds of goods and purposes they might decide to pursue, whether individually or collectively, as distinct from criticising whatever prevents their being able to make such decisions in a properly reflective and autonomous manner, as individuals or as citizens.

One can put this by saying that, to the extent that Habermas conceives of the criticism of colonisation in ethical terms, what is legitimately criticised must be

\footnotetext{
22 The context for this passage is Habermas's discussion of different 'paradigms of welfare', in $B F N$ ch. 9, and his concern about possible threats to individual autonomy. I ignore here the distinction between moral and ethical autonomy: on this and other aspects of Habermas's discussion, see Cooke 1999.
} 
restricted to matters of 'procedure' (using this term to include both individual and collective forms of autonomy), and must exclude matters of 'substance'. ${ }^{23}$ However, it must be emphasised that this restriction applies to the critical judgments that may legitimately be made by critical social theorists or philosophers, not to those made by citizens, who are 'permitted' to make substantive decisions about collective goals and goods. That is, his view of ethics (in BFN) is analogous to his more familiar view of moral judgments, including those about justice. Philosophers can demonstrate, through rigorous argumentation about the presuppositions of communication, what is required procedurally for (valid) decisions to be made about justice, and on the basis of these criteria, critical social theorists can identify and criticise the social conditions that prevent or undermine the existence or proper application of these procedures. But they cannot 'themselves' make substantive judgments.

This exclusion of substantive ethical judgments from critical social theory is one of the main ways in which Habermas distinguishes his position from that of Marx. Thus, in a paper discussing 'the meaning of socialism today', he criticises what he regards as the unfortunate Hegelian influence on Marxism:

"[...] a totalizing knowledge of this sort feels in a position to make clinical evaluations of the degree of alienation, or success, of particular forms of life in their entirety. This explains the tendency to see socialism as a historically privileged form of concrete ethical practice, even though the most a theory can do is describe the conditions necessary for emancipated forms of life. What concrete shape these take is something for those eventually involved to decide amongst themselves." (Habermas 1990, 12)

However, and returning now to the text of $T C A$, I will argue that there are certain crucial points at which Habermas himself characterises, and implicitly criticises, colonisation in substantive ethical terms (albeit perhaps not 'totalising' ones). That is, I will try to show that he does not in fact restrict himself to what is permitted by his 'official meta-theory'. I shall further argue that this ethical conception of colonisation commits him to a description of the colonising domain of the economy that is incompatible with its conceptualisation as 'system', and indeed renders the economy itself a possible object of substantive ethical criticism. For convenience, I shall now use the term 'ethical' as shorthand for 'substantively ethical'.

\footnotetext{
23 See note 3 above: my apparent disagreement with Honneth 1996, about whether Habermas should be seen as 'excluding ethics', is largely removed once this distinction is made. Cf. the distinction made by 'perfectionist liberals' who accept state action to promote the 'ethical ideal' of autonomy, but not to favour any specific ways in which this might be exercised. A notable exception is Raz 1986; 1994, who argues that the value of autonomy depends on that of the options chosen, and that the state has a responsibility to ensure the provision of valuable options (themselves dependent on 'social forms'). See also Sher 1997.
} 


\section{Habermas: Colonisation with Ethics}

This 'unofficial' (and unrecognised) use of ethical concepts, I suggest, is especially evident towards the end of volume II of TCA, where Habermas returns to his earlier discussion of Weber's account of rationalization (in chapter II of volume I) and reassesses it in light of his own. He argues that although his depiction of various problematic features of modern society was often illuminating, Weber failed to explain these adequately or convincingly. He focuses especially on Weber's claim that (as Habermas puts it):

"To the degree that the Protestant ethic of the calling ceased to place its stamp on the private conduct of life, the methodical-rational way in which bourgeois strata led their lives was displaced by the utilitarian life-style of 'specialists without spirit' and the aesthetichedonistic life-style of 'sensualists without heart', that is, by two complementary ways of life which soon became mass phenomena." $(T C A \text { II } 323)^{24}$

Weber, says Habermas, tried to explain this development in terms of "an antagonism between [different] value spheres with their own inner logics". But it is better understood in terms of colonisation:

"It is not the irreconcilability of cultural value-spheres [...] that is the cause of one-sided life-styles [...]; their cause is the monetarization and bureaucratisation of everyday practices both in the private and public spheres [...]. To the degree that the economic system subjects the life-forms of private households and the life conduct of consumers and employees to its imperatives, consumerism and possessive individualism, motives of performance and competition gain the force to shape behaviour. The communicative practice of everyday life is one-sidedly rationalized into a utilitarian lifestyle; this media-induced shift to purposive-rational action orientations calls forth the reaction of a hedonism freed from the pressures of rationality." (TCA II 325)

What is significant here, for my purposes, is that Habermas makes no attempt to question or distance himself from Weber's actual depiction of these life-styles, which is clearly intended to present them in a critical light, as ethically undesirable ways for people to conduct their lives. This is not because Habermas is concerned here only with questioning Weber's explanation, since when he goes on to provide his alternative to this, in terms of colonization, he makes use of concepts which are, I would argue, just as much ethical in character as Weber's. The colonized lifeworld is thus depicted by Habermas in terms that should not belong to a critical social theory that excludes, as a matter of meta-theoretical

\footnotetext{
24 The passage continues: "The two life-styles can be strikingly represented by different personality types, but they can also take hold of the same person. With this fragmentation of the person, individuals lose their ability to give their life-histories a certain degree of consistent direction." But I shall ignore the further issues raised by this.
} 
principle, any evaluation of, and hence any reference to, the specific ways in which people lead their lives. A 'one-sided lifestyle' is, after all, precisely a style or way of living one's life, and to draw attention to its one-sidedness is only relevant from the standpoint of some ethical ideal of 'well-roundedness' or the like.

What is problematic here, in terms of Habermas's 'official' position, can be seen in more detail by considering one of the concepts that he introduces in the above passage, possessive individualism (and similar points could be made about the others). He does not say what he means by this, but it seems reasonable to assume that he has something like the following in mind. ${ }^{25}$ Possessive individualists, let us say, are people who conceive as their chief good, and hence pursue as their main goal, the acquisition of private property; they find the possession and exercise of their ensuing right to do with, and dispose of, this property as they please, a great source of satisfaction; they conceive of what they own primarily as assets that could be used to acquire others (rather than, say, regarding their house as a home); they view other individuals either as competitors or as useful means to achieve their own goals; they think of themselves and/or their bodies as something they 'own'; and so on.

Understood in terms such as these, possessive individualism is open to criticism on ethical (and also moral) grounds. But this is precisely the kind of criticism that Habermas is committed to avoiding, since it would be concerned with the substantive merits and defects of this way of leading one's life. What (if anything) is objectionable about possessive individualism is not that it manifests a failure of autonomy or self-determination. Nor, to return to Habermas's concept of 'functional pathologies', does it manifest a loss of meaning, an absence of norms, or a medically certifiable failure of ego-development (see TCA II, 142, quoted on p. 305 above). Rather, the appropriate form of criticism would involve judgments about the merits or defects of specific motives and relationships, not 'the absence of meaning'; about the desirability of particular norms, not 'normlessness', and about the virtues or vices of specific forms of identity, not their total lack.

So if possessive individualism is properly regarded as a feature of the colonized lifeworld, as Habermas implies that it is, this means that colonization is itself being conceived in ethical terms. The colonized lifeworld is being characterised in terms that make it an intelligible object of criticism only if that criticism is itself based on distinctively ethical considerations. This represents a radical departure from Habermas's own conception of colonization as something that is appropriately criticized only in non-ethical terms. But it also has a further implication that would be equally problematic (for him). For if the colonized domain is to be characterised in these kinds of ethical terms, this must also be so for the colonizing domain. And in the case of colonization by the economy, this would only be possible if Habermas's theoretical understanding of the economy is rejected.

25 Habermas's use of this concept derives from the work of C. B. Macpherson, to whom he refers in his earlier and more extensive discussion of this in Habermas 1975, which 'pre-dates' his theory of colonisation. 
To show why this is so, I will again use the example of possessive individualism. Colonization is ('by definition') the carrying over or replication of features of the colonizing domain to the colonized domain. So if possessive individualism is to count as colonization, it must be that some set of attitudes, motives, relationships etc. that are typical of, and perhaps essential to, how people conduct themselves in modern market economies are being carried over into the private sphere. A possessive individualist is, one might say, someone who acts in every social domain 'as if' it were the economic domain. But if the economy is conceptualized only as the systematic application of instrumental or strategic rationality, combined with the use of money as a non-linguistic steering medium, then it lacks the specific features that are supposedly being carried over to the lifeworld in the case of possessive individualism.

Habermas fails to recognize this problem at least partly, I suggest, because he tends to misrepresent the nature of instrumental rationality at crucial points in his account of colonisation. Strictly speaking, instrumental rationality is a matter of calculating and adopting the most effective means to achieve some given end or goal. Its definition thus makes no reference to the specific 'content' of that goal, not even to whether it is self-interested rather than altruistic. ${ }^{26}$ But Habermas quite often talks of it as if it were inherently tied to egocentric goals, as in the following passage, where he is describing the 'decoupling' of system (including economy) from lifeworld:

"Purposive activity is freed from normative contexts in a more radicalized sense. Up this point, action oriented to success remained linked with norms of action and embedded in communicative action within the framework of a task-oriented system of social cooperation. But with the legal institutionalization of the monetary medium, success-oriented action steered by egocentric calculations of personal utility loses its connection to action oriented by mutual understanding." (TCA II 196; my italics)

Now it may well be true, at least as a first approximation, that economic actors in modern market economies act on the basis of 'egocentric calculations of personal utility'. It is then perfectly intelligible to depict colonization, as Habermas does in the passage quoted earlier, as manifested by "one-sided rationalization into a utilitarian lifestyle" (TCA II 325). However, this only makes sense because what is being 'carried across' to the lifeworld is not instrumental rationality 'as such', or 'by itself', but 'instrumental rationality in its specifically economic form', i.e in association with the specific motivations and attitudes of economic actors.

Further, if colonization is to be manifested by possessive individualism, an even greater degree of specificity must be assumed. It is not just a matter of economic agents being self-interested, but of their conceiving their interests as consisting in the acquisition of private property, and for this to be possible, the complex institutions that define this 'good', and enforce the rules governing its

\footnotetext{
26 Habermas seems to recognise this quite clearly in his discussion of pragmatic reasoning in Habermas 1993, 3 and 9, though on page 6 he again imports an assumption of egocentricity.
} 
transfer etc, must be in place. It is only if 'the economy' is conceptualised in this way, i.e. as possessing features over and above those that Habermas attributes to it, that it can intelligibly generate the colonizing effects that he attributes to it. And once it is conceptualized in this way, it becomes itself a possible object of ethical evaluation: that is, one can raise questions not only about the damage that may be done to the colonised domain, but about the value of the social relationships and institutions of the colonizing domain itself. Once colonization by the economy is understood in ethical terms, so too can the economy. ${ }^{27}$

\section{Social Criticism, Ethics and Social Science}

I began this paper by endorsing Honneth's view that in the past three decades, social criticism has been concerned predominantly with issues of justice, to the exclusion of ethical issues. I then looked in turn at Rawls's Theory of Justice, and Habermas's Theory of Communicative Action, taken as representing, in exemplary fashion, two of the most influential theoretical schools of social philosophy during this period. In both texts there is an apparent commitment to the exclusion of substantive ethical judgments as a basis for social criticism, albeit for different reasons. But I argued that in both we can find certain concepts and claims which, when their theoretical implications are followed through, lead us to the critical evaluation of economic institutions on substantive ethical grounds.

In each case the elements I have identified are not only minor, and untypical of the text as a whole, but they have gone largely unnoticed by commentators and critics. They point, as it were, to a path not taken. That it was not taken is regrettable, I would argue, though I shall not do so here. But it can at least be said that the recent history of social criticism would have been very different had these elements in $T J$ and $T C A$ (and the issues raised by them) received anything like the critical attention given to their dominant concerns with questions of justice (and indeed democracy, too). And in that 'alternative history' one can imagine the debates that might have taken place about the ethical merits and defects of modern market economies, not only between Habermas and Rawls, but also between both of them and MacIntyre, whose work would then have formed part of the mainstream. ${ }^{28}$

I want now to comment on some of the areas of agreement and disagreement between them. My purpose in doing so is not to resolve their disagreements, but to explore an issue that has been implicit in much of the preceding discussion, namely the relationship between what can be called the normative and empiri-

\footnotetext{
27 Habermas's theorization of the economy as system has been widely criticized (e.g. McCarthy 1991); especially important for my purposes here are the arguments in Berger 1991 and Forbath 1998, who rightly insist on conceptualising economies as (variable) social institutions. But my argument differs somewhat from theirs: instead of criticizing the idea of ' $n o r m$-free sociality', I criticize that of ethics-free sociality, and I argue that what Habermas himself says about colonization implies that the economy cannot be like this.

28 The ghostly presence of both Marx and Weber would doubtless also have been felt. See Breen 2005 on the respective relationships of Habermas and MacIntyre to Weber, and Breen 2007 for a defence of MacIntyre's view of work as against Habermas'.
} 
cal bases of their claims, and hence more generally the respective roles of these elements in social criticism. I shall comment first on the normative aspects of their judgments about economic institutions, i.e. on the ethical criteria by reference to which economic institutions are being evaluated, and how these may be justified.

I have already noted the strong similarities between Rawls's conception of social unions and MacIntyre's of practices, and both implicitly reject Marx's ethical privileging of work over other kinds of practice or social union, whilst nonetheless attributing considerable significance to this. There are also important connections between Rawls's concept of private society and Habermas's concept of possessive individualism. One might put this by saying that at least part of what is involved in possessive individualism is the extension to all social domains, including the household, of the kinds of motivations and relationships in the economic domain that Rawls would regard as typifying private society.

Rawls would agree with Habermas in opposing this. So too would MacIntyre. But unlike both of them-here as throughout this discussion, 'according to my earlier analysis of their views'-MacIntyre would not attribute any positive value to private society, even when restricted to the economic sphere. Nor, likewise, would he accept the idea that there is nothing ethically problematic about the role of instrumental reason in the management of modern enterprises and the state. For MacIntyre, preventing colonisation by the economy and state is a matter of limiting the spread of something bad, not of keeping in its place something that is good when thus located.

So if Rawls and Habermas are to justify their quite different normative view of colonisation, they need to develop a pluralistic theory of social goods and their institutional locations. Indeed, this is something that MacIntyre himself needs to do, along with Rawls, with respect to their 'shared' normative endorsement of social unions and practices. For it is implausible to believe that the value of each specific kind of practice or social union resides solely in the features that it has in common with other kinds: there must also be something valuable about the specific character of each. What is required, perhaps, is some general account of 'human functionings', of the kind developed by Nussbaum, which would enable the specific contribution to each of these made by different kinds of practices to be evaluated. ${ }^{29}$

However, the judgments about economic institutions made by MacIntyre, Rawls and Habermas depend not only on normative considerations, but also on empirical claims about the actual character of the social world and why it operates in the way that it does. Indeed many of the disagreements between them seem to depend more on empirical than normative issues. Most obviously, the evaluations of market economies presented by Rawls and MacIntyre differ radically, despite their ethical ideals of social unions and practices having so much in

\footnotetext{
29 See Nussbaum 1990; 2000. But Nussbaum's account arguably gives insufficient attention to the significance of social institutions, and institutionally dependent practices, as 'conditions of possibility' for various goods. In this respect Raz's view of 'social forms', and more generally his pluralistic account of socially constituted and non-substitutable goods, is especially valuable (Raz 1986). Habermas would need to accept that theories of this kind have a legitimate part to play in the process of critical self-reflection by members of a political community.
} 
common, and the difference between these evaluations are by no means wholly due to their normative disagreement about the value of private society. In particular, Rawls believes that work can have the character of social union in a certain kind of market economy, whereas MacIntyre claims that market economies are incompatible with work being conducted as a practice. Further, whereas MacIntyre claims that practices are confined to the margins, Rawls believes that social unions flourish in many areas of social life in modern society. (And were Rawls to accept Habermas's view of the colonising tendencies of market economies, he would no doubt be more wary of endorsing them, whilst justifiably insisting that Habermas provide some evidence of the incipient presence of possessive individualism.)

To resolve these kinds of empirical disagreement (and more generally, for social critics to engage seriously in the ethical evaluation of market economies), what is clearly required is rigorously conceived and conducted social scientific enquiry. The questions or problems it addresses will be shaped by specific ethical values. Further, it will necessarily make use throughout of normative concepts informed by these, such as private society, practices, or possessive individualism. But there is no reason to believe that this threatens the objectivity of such enquiry (for example, by making the acceptance of its results depend on the endorsement of those values). One does not need to exclude such concepts in order to protect the objectivity of social science. Their presence poses no threat to this, provided that they are operationalisable, i.e. that evidence-sensitive criteria for their application can be specified, so that, for example, one can determine empirically whether a particular social activity does in fact possess the characteristics of a social union, as distinct from those of private society. (Are there shared ends? Do the people involved value the activity in purely instrumental terms? And so on). ${ }^{30}$

Provided this can be done, it is then possible to distinguish between the question of whether the 'object' actually has these characteristics (and the justification provided in answering this), and the question of whether, if it were to do so, this would be ethically desirable (and the justification given for this). Thus the (empirical) question of whether, for example, the work performed in a particular society with a market economy has the characteristics of social unions, is distinct from the (normative) question of whether, if it does not, this would be undesirable, and hence a justifiable ground for criticising that society. ${ }^{31}$

But social scientific enquiry, if it is to explore and answer the kinds of questions relevant to social critics, will have to go well beyond these relatively straight-

\footnotetext{
${ }^{30}$ It is hard to see how such concepts could function in social criticism, ie in making judgments about some kind of social institution or activity, unless it were possible to show, empirically, that the object of criticism actually possesses the feature referred to in the critical judgment. It is equally hard to see how social enquiry could have much to say about matters of human concern if normative concepts are excluded from its vocabulary, let alone from the questions it addresses.

31 The position I am taking here is based on the arguments presented in Keat 1981, which draw on Ernest Nagel's defence of objectivity in social science (Nagel 1961), and especially his distinction between characterising and appraising judgments. The judgments made by social critics are appraisals, which depend on the relevant characterising judgments being correct, but the truth of the latter is not sufficient to justify the former.
} 
forward 'descriptive' issues. In the case just noted, it will be important to know why work in this particular society fails to be social union-like: is it because economic production is governed by markets, or for some other reason? And if the former, would social union-like work be absent in any society with a market economy, or only if that market economy is of a particular kind? And in many cases, trying to answer these kinds of question will require the comparative study of economic institutions, comparing these with respect to the possibilities they provide for the realisation of particular ethical ideals, and also investigating what combinations of valued goods are co-realisable in a given set of institutions. ${ }^{32}$

In order to address these kinds of questions, social scientific enquiry must itself be conceived and practised in a certain way. It needs the theoretical depth and explanatory power of a realist rather than a positivist understanding of science (Bhaskar 1979; Keat/Urry 1982; Sayer 2000); it must include a distinctively interpretive element (but without allowing this to displace the aim of causal explanation), given that concepts such as practices and possessive individualism make essential reference to social meanings and experience; and it needs to recognise what I called the facts of 'generic sociality' that Rawls rightly sees as obtaining both in social unions and in private society (and hence, inter alia, in market economies). ${ }^{33}$

What it not needed, however - if the preceding argument about objectivity is correct - is some special kind of social science that is itself 'essentially critical': an epistemologically distinctive form of social enquiry with its own criteria of validity, such that the truth or falsity of its descriptive and explanatory claims is logically dependent on that of the ethical values (and moral principles) endorsed by the social critic. In other words, social criticism does not require a so-called critical social science, conceived as rejecting the distinction between empirical and normative, as overcoming the separation of facts and values, and so on.

What is required by social criticism is not critical social science, but on the one hand, rigorously theorised and empirically grounded social enquiry that is guided in the questions it addresses, and in the concepts it employs, by specific ethical concerns, and on the other hand, philosophical reflection on the nature (and variety) of human goods and flourishing, informed by rich descriptions of actual people's lives. Distinguishing between social science and ethics does not prevent them being brought into a relationship with one another that makes social criticism possible here as elsewhere, separate identities contribute to, rather then detract from, constructive relationships.

\footnotetext{
32 See Keat 2008b for discussion of recent literature on 'varieties of capitalism', especially Hall/Soskice 2001, in which I argue that 'production as a practice' is more likely in coordinated market economies such as Germany's than in liberal market economies such as the UK's.

33 All three requirements point towards institutionalist rather than neo-classical economics, and arguably towards the 'old' rather than the 'new' institutionalism (Hodgson 2000); see also Note 9 above.
} 


\section{Bibliography}

Anderson, E. (1990), The Ethical Limitations of the Market, in: Economics and Philosophy 6, 179-205

Arneson, R. (1987), Meaningful Work and Market Socialism, in: Ethics 97, 517-545

Berger, J. (1991), The Linguistification of the Sacred and the Delinguistification of the Economy, in: A. Honneth/H. Joas (eds.), Communicative Action, Cambridge, $165-180$

Bhaskar, R. (1979), The Possibility of Naturalism, London

Breen, K. (2005), Negotiating the 'Iron Cage': Habermas, Arendt and MacIntyre in Response to Weber, Thesis (PhD), University of Edinburgh

- (2007), Work and Emancipatory Practice: Towards a Recovery of Human Beings' Productive Capacities, in: Res Publica 13, 381-414

Cooke, M. (1997), Authenticity and Autonomy: Taylor, Habermas, and the Politics of Recognition, in: Political Theory 25, 258-288

- (1999), Habermas, Feminism and the Question of Autonomy, in: P.Dews (ed.), Habermas: A Critical Reader, Oxford, 178-210

Dworkin, R. (1978[1985]), Liberalism, in: A Matter of Principle, Oxford, 181-204

Durkheim, E. (1984[1893]), The Division of Labour in Society, W. D. Halls (trans.), London

Forbath, W. (1998), Short-Circuit: A Critique of Habermas's Understanding of Law, Politics and Economic Life, in: M. Rosenfeld/A. Arato (eds.), Habermas on Law and Democracy: Critical Exchanges, Berkeley, 272-286

Habermas, J. (1973[1975]), Legitimation Crisis, T. McCarthy (trans.), Boston

- (1981[1984]), The Theory of Communicative Action, vol. 1, T. McCarthy (trans.), Cambridge

- (1981[1987]), The Theory of Communicative Action, vol. 2, T. McCarthy (trans.), Cambridge

- (1990), What Does Socialism Mean Today?, in: New Left Review 183, 3-21

- (1991[1993]), On the Pragmatic, the Ethical, and the Moral Employments of Practical Reason, in: Justification and Application, C. Cronin (trans.), Cambridge, 1-18

- (1992[1996]), Between Facts and Norms, W. Rehg (trans.), Cambridge

Hall, P./F. Soskice (2001) (eds.), Varieties of Capitalism: The Institutional Foundations of Comparative Advantage, Oxford

Hodgson, G. M. (2000), What Is the Essence of Institutional Economics?, in: Journal of Economic Issues 39, 317-329

Honneth, A. (1996), Pathologies of the Social: The Past and Present of Social Philosophy, in: D. Rasmussen (ed.), Handbook of Critical Theory, Oxford, 369-396

- (2005), Reification: A Recognition-Theoretical View, in: Tanner Lectures on Human Values, Berkeley

Keat, R. (1981), The Politics of Social Theory: Habermas, Freud and the Critique of Positivism, Oxford

- (1993), The Moral Boundaries of the Market, in: C. Crouch/D. Marquand (eds.), Ethics and Markets, Oxford, 6-20

- (2000), Cultural Goods and the Limits of the Market, London

- (2007), Ethics or Morality? Habermas on European Identity, Manuscript, School of Social and Political Studies, University of Edinburgh

- (2008a), Ethics, Markets and MacIntyre, in: Analyse $\& 6$ Kritik 30, 382-396

- (2008b), Practices, Firms and Varieties of Capitalism, in: Philosophy of Management 7, 77-91 
- (2009), Anti-perfectionism, Market Economies and the Right to Meaningful Work, in: Analyse \& Kritik 31

- /J. Urry (1982), Social Theory as Science, $2^{\text {nd }}$ edition, London

Kymlicka, W. (2002), Contemporary Political Philosophy, $2^{\text {nd }}$ edition, Oxford

MacIntyre, A. (1981), After Virtue, Notre Dame

- (1994), A Partial Response to My Critics, in: J.Horton/S. Mendus (eds.), After MacIntyre, Cambridge 283-304

- (1998), Politics, Philosophy and the Common Good, in: K. Knight (ed.), The MacIntyre Reader, Cambridge, 235-252

- (1999), Dependent Rational Animals, London

McCarthy, T. (1991), Complexity and Democracy: or the Seducements of Systems Theory, in: A. Honneth/H. Joas (eds.), Communicative Action, Cambridge, 119-139

Meade, J. (1964), Efficiency, Equality and the Ownership of Property, London

Nagel, E. (1961), The Structure of Science, New York

Nussbaum, M. (1990), Aristotelian Social Democracy, in: R. Douglass et al. (eds.), Liberalism and the Good, 203-252

- (2000), Women and Human Development: The Capabilities Approach, Cambridge Rawls, J. (1971[1999]), A Theory of Justice, revised edition, Oxford

- (2001), Justice as Fairness, E. Kelly (ed.), Oxford

Raz, J. (1986), The Morality of Freedom, Oxford

- (1994), Ethics in the Public Domain, Oxford

Sayer, A. (2000), Realism and Social Science, London

Sher, G. (1997), Beyond Neutrality: Perfectionism and Politics, Cambridge

Walzer, M. (1983), Spheres of Justice, Oxford

Warnke, G. (1995), Communicative Rationality and Cultural Values, in: S. White (ed.), The Cambridge Companion to Habermas, Cambridge, 120-142 